\title{
Evaluating the quality of hotel services based on tourists' perceptions and expectations: The case study of Armenia
}

\author{
Gayane Tovmasyan \\ AMBERD Research Center, \\ Armenian State University of Economics \\ Management Chair, Public Administration Academy \\ Republic of Armenia \\ tovmasyangayane@yahoo.com
}

\begin{abstract}
The evaluation of hotel service quality is very important for hotels in terms of revealing the gaps in their performance and accomplishing certain actions of improvement. As in Armenia there is no general instrument for evaluating hotel quality, this article aims at processing such an instrument - ARMQUAL, which should be used by hotels. The instrument was processed based on the analysis of international experience, literature review and current situation in Armenian hotels. Main factors that are important for evaluating quality in hotels were taken into account and based on them a questionnaire was prepared. ARMQUAL is calculated based on perceptions, expectations of visitors, weighted by the importance of factors. This instrument is based on three dimensions: tangibles and appearance, availability and comfort, staff competence and helpfulness. Testing of the instrument was done in two hotels, based on which the main problems were revealed. Importance-Performance Analysis was done to determine the main quadrants of quality dimensions and also to find the gaps between the level of performance and importance in order to define the main strategic actions. The study shows that guests evaluated the factors of staff competence and helpfullness high. Despite some complaints regarding physical devices, the overall weighted index of ARMQUAL for both hotels was positive. The results also establish the interrelationship between satisfaction and loyalty. Besides, the findings were analyzed via Crosstabulations with Pearson Chi-square coefficient test and significant relationships were found between the perception, expectations and the desire to visit again and advise others. The majority of the hotels' guests would like to return again and advise others to visit the same hotels. This indicates that satisfaction with the quality level of hotel services leads to loyalty.
\end{abstract}

Keywords: hotel quality, loyalty, survey, perception, expectation, importance, IPA, ARMQUAL, Armenia

JEL Classification: L83, Z32 


\section{INTRODUCTION}

In order to be competitive, hotels must provide high quality of services. The quality of hotels is a component which influences on the overall satisfaction level in tourism. Tourists are satisfied when their expectations have come true and this indicator influences their loyalty. Besides, a satisfied tourist may tell others to visit the same hotel. Thus, hotels should take actions for evaluating the service quality and taking improvement actions if necessary.

There are 652 hotel facilities in Armenia, and only 11 of them have qualification stars. The number of tourists in Armenia was 1651782 in 2018, 307473 of which have stayed in hotels (The socio-economic situation in January in the RA, 2019). Now some of the hotels may have evaluation surveys, their visitors fill them up and also write complaints, but there should be also an instrument for quality evaluation which will be used in all hotels and based on the results the hotels may be qualified by the state.

The article aims at processing an instrument for evaluating the quality of hotel services in Armenia. The instrument was named ARMQUAL - Armenian evaluation tool of hotel quality. The instrument was processed based on analyzing the international experience, current situation in Armenian hotels, and defining the main factors that are important for evaluating hotel quality in Armenia. The existing instruments from international practice cannot be automatically used here; we need some changes, improvements, taking into account the existing situation in the country. That is why questions in the survey refer to all the important factors that according to our analyses have impact on quality level. ARMQUAL is based on tourists' perceptions and expectations. The index was formulated by weighting the importance of the factors. For ARMQUAL we have developed a survey of 32 questions. The quality dimensions which consist of 24 questions were divided into 3 major groups: tangibles and appearance, availability and comfort, staff competence and helpfulness. The analyses were done in two different hotels and the ARMQUAL instrument was tested on them. As a result, the main gaps which may distort the quality of hotel services are revealed.

The structure of the paper is as follows: first, the main literature sources about hotel quality and its evaluation are analyzed. Then the methodological part describes how this research was done. Data analysis shows the main findings and results, based on which the conclusions were then formulated.

\section{LITERATURE REVIEW}

Service quality is a measure of how well the level of a delivered service matches customer expectations (Lewis \& Bernard, 1983).

According to Petrick (2004) quality is the best predictor of intentions to repurchase. Quality has both a moderated and direct effect on behavioral intentions.

According to Ruyter, Wetzels and Bloemer (1998), quality has an impact on customer preference and the willingness to recommend the service to other consumers.

Zeithaml (1988) suggests that perceived value is the customer's overall assessment of the utility of a product based on perceptions of what is received and what is given.

Parasuraman et al. (1985) have mentioned the determinants of service quality: access, communication, competence, courtesy, credibility, reliability, responsiveness, security, tangibles, understanding the customer, which was later reduced to five.

One of the most used measures of service quality is SERVQUAL (Cronin \& Taylor 1992). The SERVQUAL questionnaire was developed by Parasuraman, Zeithaml, and Berry (1988).

There are seven major gaps in the service quality concept (Shahin, 2006):

Gap 1: Customers' expectations versus management perceptions: as a result of the lack of a marketing research orientation, inadequate upward communication and too many layers of management.

Gap 2: Management perceptions versus service specifications: as a result of inadequate commitment to service quality, a perception of unfeasibility, inadequate task standardization and an absence of goal setting. 
Gap 3: Service specifications versus service delivery: as a result of role ambiguity and conflict, poor employee-job fit and poor technology-job fit, inappropriate supervisory control systems, lack of perceived control and lack of teamwork.

Gap 4: Service delivery versus external communication: as a result of inadequate horizontal communications and propensity to over-promise.

Gap 5: The discrepancy between customer expectations and their perceptions of the service delivered: as a result of the influences exerted from the customer side and the shortfalls (gaps) on the part of the service provider. In this case, customer expectations are influenced by the extent of personal needs, word of mouth recommendation and past service experiences.

Gap 6: The discrepancy between customer expectations and employees' perceptions: as a result of the differences in the understanding of customer expectations by front-line service providers.

Gap 7: The discrepancy between employee's perceptions and management perceptions: as a result of the differences in the understanding of customer expectations between managers and service providers.

Another index for measuring consumers' expectations for service quality in the hotel experience is LODGSERV, which was designed by Knutson et al. (1990), and it confirms the five generic dimensions of service quality hypothesized by Parsuraman et al.: Tangibility, Reliability, Responsiveness, Assurance, and Empathy.

Mei et al. (1999) developed the HOLSERV instrument, stating that there are three dimensions of service quality: employees, tangibles and reliability.

If the above-mentioned measures describe the evaluation of hotels' quality, other measures are used to evaluate customer satisfaction with the trip. Swedish Customer Satisfaction Barometer (SCSB) was created in 1989 as the first national customer satisfaction index for domestically purchased and consumed products and services (Fornell, 1992). It contains two primary antecedents of satisfaction: perceptions of a customer's performance experience with a product or service, and customer expectations regarding that performance. The increased satisfaction will decrease customer complaints and increase customer loyalty (Johnson et al., 2001).

The American Customer Satisfaction Index (ACSI) model was developed in 1994. This model shows that when perceived value and perceived quality increase, customer satisfaction should increase. The main differences between the SCSB and the ACSI models are the addition of a perceived quality component (Fornell et al., 1996).

The Norwegian customer satisfaction barometer (NCSB) model is different from the ACSI model. It uses SERVQUAL to measure service quality, focuses on the introduction of corporate reputation and replaces customer complaints with complaint handling (Yang et al., 2000).

The European Customer Satisfaction Index (ECSI) model contains the traditional latent variables: perceived quality, expectations, perceived value, satisfaction index, loyalty and two optional latent variables: image and complaints (Bayol et al., 2000).

A study done in Hong Kong hotels found that travelers have high expectations of service quality, however, there are differences in the various dimensions. "Responsiveness" and "Empathy" are more important to business travelers than leisure travelers (Heung \& Wong, 1997).

An exploratory study of 369 hotel guests at six Norwegian hotels identified four stable and robust factors of atmosphere: distinctiveness, hospitability, relaxation, and refinement (Heid \& Grønhaug, 2009).

Another study in China's hotel industry identified that "staff skill and performance" and "extra amenities provided" were the determinants of tourists' choice intention (Qu \& Tsang, 1998).

A recent study showed how price, service-quality expectations and emotions, that play a key role in customers' assessments of offers, interrelate. The model was tested on a sample of 841 hotel customers and the results showed that the stronger the customers' emotions, the more likely they were to perceive the product as cheap and the higher their predictive expectations of service quality. Additionally, although the observed price level influenced customers' predictive expectations, the perception of a product as expensive or cheap did not (Pelegri'n-Borondo et al., 2017). 
Another study was done for finding out the impact of hotel service quality on the loyalty of customers. For the research a questionnaire was applied and the SERVQUAL was combined with loyalty assessment (SERVQUALOYAL methodology). The research showed that perceived higher quality of hotel services results in higher customer loyalty. This means that customers highly evaluating service quality were more loyal, tended to use the hotel services repeatedly and recommend it to friends (Jasinskas et al., 2016).

Studies also show that higher prices of hotels may signal higher service quality (Chiu \& Chen, 2014).

Guest satisfaction is also influeced by hotel locations. Yang, Mao, and Tang (2018) using data from 8,185 online reviews of 220 Los Angeles hotels checked in during a 1-year period suggested that a property's accessibility to attractions, airports, universities and public transportation, as well as green spaces, bodies of water, and local businesses are significant determinants for guest satisfaction.

An impirical study was conducted in Macau for finding out the interrelationships between hotel image, service quality, perceived value, customer satisfaction, hotel reputation, customer commitment, and customer loyalty. 442 respondents were questioned for the study and the results indicate that hotel image is an antecedent of hotel reputation, and all the other factors mentioned above have a crucial role in building customer loyalty (Lai, 2019).

A study in seven high-end hotels in Spain's Canary Islands among 288 guests showed that satisfaction with service recovery has a direct effect on loyalty, which in turn has a strong effect on customer citizenship behaviors (Zoghbi-Manrique-de-Lara, 2014).

A new and interesting research was done in the hotels of Spanish hotel chain located on the islands of Lanzarote, Fuerteventura, Gran Canaria and Tenerife. 18,944 individuals participated in a survey during 2016-2017. The aim of the study was to analyze the ability of managers' transformational and authentic leadership to predict customer satisfaction. The results indicated that the transformational subscales of idealized influence and intellectual stimulation and the authentic subscales of relational transparency and balanced processing predict overall customer satisfaction (Baquero et al., 2019).

Another interesting study was done in Albania to find out the extent to which innovativeness and innovation behavior affects tourism SMEs performance. By conducting 215 face-to-face interviews and corresponding tests, the authors indicate that there is a significant effect of innovativeness on innovation behavior. The results of the study suggest that if SMEs managers/owners are open towards innovation, accept new ideas, encourage new resources for innovation, the more innovation into the SMEs will take place. Innovativeness is an attitude for allowing the business to achieve sustainable competitive advantage. While innovativeness does not affect SMEs performance directly, its indirect effects through the mediation role of innovation behavior are significant. The results indicate that the more tourism sphere SMEs innovate in terms of ICT, cooperation (associations, networks), the more their performance will positively increase (Domi et al., 2019).

\section{METHODOLOGY}

The aim of the study was to evaluate hotel service quality in Armenian hotels based on tourists' perceptions and expectations. For that purpose, a survey was done in two hotels among 50 tourists in each place during 2018. The tourists were asked to fill in the questionnaire consisting of 32 questions, 24 of which were specific questions, which they rated according to their level of perception (Very dissatisfied-1, Dissatisfied-2, Somewhat satisfied-3, Satisfied-4, Very satisfied-5), expectations (Very low-1, Low-2, Medium-3, High-4, Very high-5) and importance for them (Not important at all-1, Not important-2, Of medium importance-3, Important-4, Very important-5).

Based on 24 quality determinants 3 dimensions of hotel quality were created: tangibles and appearance, availability and comfort, staff competence and helpfulness. Thus, I have created an instrument for measuring hotel service quality in Armenian hotels: ARMQUAL.

The questionnaire of ARMQUAL instrument is placed in Appendix 1. 
This instrument was named so showing its belonging to Armenian hotels (ARMQUAL- Armenian evaluation tool of hotel quality or Armenian hotels' quality). As all the other methods described in the literature review and used in practice do not include all the questions and issues that I wanted to reveal, so I processed my own questionnaire. The calculation methodology of this instrument is the following: after analyzing the level of perception, expectations and importance of the factors of hotel services for respondents, I have calculated two indexes: unweighted and weighted. The unweighted quality describes difference between perceptions and expectations (P-E). The weighted index includes also the importance of factors for people ((P-E)*I).

Here I want to introduce the main methods for calculations described in the literature review.

The following is the measure of SERVQUAL (Sanjay \& Garima, 2004).

$$
S Q_{i}=\sum_{j=1}^{k}\left(P_{i j}-E_{i j}\right)
$$

where: $\mathrm{SQ}_{\mathrm{i}}=$ perceived service quality of individual ' $\mathrm{i}$ ',

$\mathrm{k}=$ number of service attributes/items,

$\mathrm{P}=$ perception of individual ' $\mathrm{i}$ ' with respect to performance of a service firm attribute ' $\mathfrak{j}$ ',

$\mathrm{E}=$ service quality expectation for attribute ' $\mathrm{j}$ ' that is the relevant norm for individual ' $' \mathrm{i}$ '.

Another measure is SERVPERF, which is a variant of the SERVQUAL scale and contains perceived performance component alone.

$$
\mathrm{SQ}_{\mathrm{i}}=\sum_{\mathrm{j}=1}^{\mathrm{k}} \mathrm{P}_{\mathrm{ij}}
$$

$\mathrm{SQ}_{\mathrm{i}}=$ perceived service quality of individual ' $\mathrm{i}$ ',

$\mathrm{k}=$ number of attributes/items,

$\mathrm{P}=$ perception of individual ' $\mathrm{i}$ ' with respect to performance of a service firm on attribute ' $j$ '.

The weighted versions of the SERVQUAL and the SERVPERF scales are:

$$
\begin{aligned}
& S Q_{i}=\sum_{j=1}^{k} I_{i j}\left(P_{i j}-E_{i j}\right) \\
& S Q_{i}=\sum_{j=1}^{k} I_{i j}\left(P_{i j}\right)
\end{aligned}
$$

where: $\mathrm{I}_{\mathrm{ij}}$ is the weighting factor, i.e., importance of attribute 'j' to an individual ' $\mathrm{i}$.'

So my calculations are similiar to weighted SERVQUAL, but the questions and determinants were processed by me.

Some results were analyzed via Crosstabulations with Pearson Chi-square coefficient testing (setting significance level $a=0.05$ ). The value of the Chi Square statistic provides a test whether or not there is a statistical relationship between the variables in the cross-classification table.

The Importance-Performance analysis (IPA) (Martilla \& James, 1977) was used to determine the gap between the importance of the factor for the customer and the perceived level of the service. The purpose of IPA was to identify which factors have competitive position and lead to customer satisfaction and choose available strategies to enhance the performance level. Besides, modified IPA matrix was processed using SPSS software. 


\section{EMPIRICAL RESULTS AND DISCUSSION}

Here are the main results of the analyses in two hotels, which will be presented as hotel $\mathrm{X}$ and $\mathrm{Y}$ (Table 1).

The survey participants were tourists from Russian Federation, USA, Georgia, Ukraine, France, Italy, Switzerland, UK, UAE, etc.

The participants had some complaints about air conditioning, bathroom conditions, elevator functioning, etc. The majority of participants would like to stay in the same hotel again, and advise others to stay.

Table 1

Some data of survey participants

\begin{tabular}{|c|c|c|}
\hline & $\begin{array}{l}\text { X hotel (\% of } \\
\text { participants) }\end{array}$ & $\begin{array}{l}\text { Y hotel (\% of } \\
\text { participants) }\end{array}$ \\
\hline \multicolumn{3}{|l|}{ Age } \\
\hline up to 25 years old & 4 & 1 \\
\hline $26-35$ years old & 32 & 18 \\
\hline $36-50$ years old & 35 & 45 \\
\hline 51 and older & 29 & 36 \\
\hline \multicolumn{3}{|l|}{ Gender } \\
\hline Male & 45 & 40 \\
\hline Female & 55 & 60 \\
\hline \multicolumn{3}{|l|}{ Level of income } \\
\hline Up to 100.000 AMD (210 US dollar, 170 Euro) & 2 & 4 \\
\hline 100.001-200.000 AMD (211-420 US dollar, 171-335 Euro) & 4 & 10 \\
\hline 200.001-300.000 AMD (421-630 US dollar, 336-500 Euro) & 1 & 9 \\
\hline 300.001-400.000 AMD (631-840 US dollar, 501-670 Euro) & 12 & 5 \\
\hline 400.001 AMD and more (841 US dollar and more, 671 Euro and more) & 81 & 72 \\
\hline \multicolumn{3}{|l|}{ Occupation } \\
\hline unemployed & - & - \\
\hline student & - & - \\
\hline state officer & 10 & 9 \\
\hline service sphere & 12 & 27 \\
\hline production sphere & 7 & - \\
\hline trade sphere & 14 & - \\
\hline other & 57 & 64 \\
\hline \multicolumn{3}{|l|}{ Would you like to stay in the same hotel again? } \\
\hline yes & 94 & 91 \\
\hline no & 4 & - \\
\hline I don't know & 2 & 9 \\
\hline \multicolumn{3}{|l|}{ Would you advice others to visit this hotel? } \\
\hline yes & 94 & 90 \\
\hline no & 4 & - \\
\hline I don't know & 2 & 10 \\
\hline \multicolumn{3}{|l|}{ What complaints or suggestions do you have? } \\
\hline I don't have any & 70 & 65 \\
\hline other & 30 & 35 \\
\hline
\end{tabular}

Source: Based on the analysis of the survey results

From Table 1 it is shown that very small percentage of respondents were up to 25 years old. Their monthly level of income was 400.001 AMD and more (841 US dollar or 671 Euro and more).

The majority of respondents said that they would like to stay in the same hotel again and would advise others to visit that hotel. Although the great part had no complaints, but some of them mentioned problems with physical facilities: they did not like bathroom conditions, had problems with the functioning of air conditioner, elevator, etc. 
Other 24 questions were specific regarding to the performance of hotels. These questions were evaluated according to the level of their perception, expectations and importance for them (Table 2).

Table 2

Specific questions of ARMQUAL questionnaire and their evaluation in two hotels

\begin{tabular}{|c|c|c|c|c|c|c|c|c|c|c|}
\hline \multirow[t]{2}{*}{ Question } & \multicolumn{2}{|c|}{$\begin{array}{l}\text { The level of } \\
\text { perception } \\
\text { (satisfaction) }\end{array}$} & \multicolumn{2}{|c|}{$\begin{array}{c}\text { The level of } \\
\text { your } \\
\text { expectations }\end{array}$} & \multicolumn{2}{|c|}{$\begin{array}{l}\text { Importance for } \\
\text { you }\end{array}$} & \multicolumn{2}{|c|}{$(\mathrm{P}-\mathrm{E})$} & \multicolumn{2}{|c|}{$\begin{array}{c}\text { Weighted Index } \\
\text { (ARMQUAL) } \\
\text { (P-E)*I } \\
\end{array}$} \\
\hline & $\mathrm{X}$ hotel & Y hotel & X hotel & Y hotel & $\mathrm{X}$ hotel & Y hotel & X hotel & $\begin{array}{c}\mathrm{Y} \\
\text { hotel }\end{array}$ & X hotel & Y hotel \\
\hline $\begin{array}{l}\text { 1. General conditions of the } \\
\text { hotel facility }\end{array}$ & 4.45 & 4.18 & 4.39 & 3.73 & 4.47 & 4.09 & 0.06 & 0.45 & 0.27 & 1.86 \\
\hline $\begin{array}{l}\text { 2. The level of cleanness in the } \\
\text { hotel facility }\end{array}$ & 4.29 & 4.09 & 4.37 & 4.27 & 4.61 & 4.55 & -0.08 & -0.18 & -0.38 & -0.83 \\
\hline $\begin{array}{l}\text { 3. The level of service in the } \\
\text { hotel facility }\end{array}$ & 4.51 & 4.64 & 4.35 & 4.09 & 4.55 & 4.18 & 0.16 & 0.55 & 0.74 & 2.28 \\
\hline $\begin{array}{l}\text { 4. The level of prices in the } \\
\text { hotel facility }\end{array}$ & 4.08 & 4.36 & 4.12 & 4.00 & 4.33 & 4.27 & -0.04 & 0.36 & -0.18 & 1.55 \\
\hline $\begin{array}{l}\text { 5. The correlation of price- } \\
\text { service quality of the hotel facility }\end{array}$ & 4.27 & 4.18 & 4.24 & 3.82 & 4.45 & 4.09 & 0.02 & 0.36 & 0.09 & 1.49 \\
\hline $\begin{array}{l}\text { 6. The quality of food in the } \\
\text { hotel facility }\end{array}$ & 4.29 & 3.64 & 4.27 & 4.00 & 4.47 & 4.00 & 0.02 & -0.36 & 0.09 & -1.45 \\
\hline $\begin{array}{l}\text { 7. The prices of food in the } \\
\text { hotel facility }\end{array}$ & 4.08 & 4.09 & 4.10 & 3.64 & 4.29 & 4.09 & -0.02 & 0.45 & -0.09 & 1.86 \\
\hline $\begin{array}{l}\text { 8. The existence of leisure } \\
\text { activities in the hotel facility }\end{array}$ & 3.98 & 3.09 & 4.08 & 3.73 & 4.22 & 3.73 & -0.10 & -0.64 & -0.43 & -2.37 \\
\hline $\begin{array}{l}\text { 9. The existence of Wi-Fi and } \\
\text { the quality of Internet connection } \\
\text { in the hotel facility }\end{array}$ & 4.57 & 4.55 & 4.51 & 4.09 & 4.73 & 4.45 & 0.06 & 0.45 & 0.29 & 2.02 \\
\hline $\begin{array}{l}\text { 10. The existence of necessary } \\
\text { things of first use in the hotel } \\
\text { facility }\end{array}$ & 4.24 & 3.82 & 4.24 & 3.64 & 4.33 & 3.82 & 0.00 & 0.18 & 0.00 & 0.69 \\
\hline $\begin{array}{l}\text { 11. Good functioning of devices } \\
\text { in the hotel room }\end{array}$ & 4.08 & 4.27 & 4.27 & 3.73 & 4.43 & 3.73 & -0.18 & 0.55 & -0.81 & 2.03 \\
\hline $\begin{array}{l}\text { 12. The existence of modern } \\
\text { devices in the hotel facility }\end{array}$ & 4.04 & 3.91 & 4.12 & 3.73 & 4.31 & 3.82 & -0.08 & 0.18 & -0.35 & 0.69 \\
\hline $\begin{array}{l}\text { 13. The bath convenience in the } \\
\text { hotel facility }\end{array}$ & 3.67 & 3.64 & 4.18 & 3.82 & 4.37 & 4.00 & -0.51 & -0.18 & -2.23 & -0.73 \\
\hline $\begin{array}{l}\text { 14. The level of competence of } \\
\text { the staff of the hotel facility }\end{array}$ & 4.55 & 4.64 & 4.31 & 4.18 & 4.43 & 4.09 & 0.24 & 0.45 & 1.08 & 1.86 \\
\hline $\begin{array}{l}\text { 15. The level of willingness of } \\
\text { the staff to help the customer in } \\
\text { the hotel facility }\end{array}$ & 4.63 & 4.64 & 4.27 & 4.09 & 4.47 & 4.36 & 0.37 & 0.55 & 1.64 & 2.38 \\
\hline $\begin{array}{l}\text { 16. Quick response of the staff } \\
\text { to your questions }\end{array}$ & 4.57 & 4.64 & 4.29 & 4.36 & 4.45 & 4.45 & 0.29 & 0.27 & 1.27 & 1.21 \\
\hline $\begin{array}{l}\text { 17. The caring and polite } \\
\text { attitude of the staff of the hotel } \\
\text { towards you }\end{array}$ & 4.69 & 4.64 & 4.33 & 4.27 & 4.51 & 4.55 & 0.37 & 0.36 & 1.66 & 1.65 \\
\hline $\begin{array}{l}\text { 18. The level of confidence } \\
\text { towards the staff of the hotel } \\
\text { facility }\end{array}$ & 4.67 & 4.45 & 4.37 & 4.36 & 4.45 & 4.00 & 0.31 & 0.09 & 1.36 & 0.36 \\
\hline $\begin{array}{l}\text { 19. The attractiveness of } \\
\text { interior of the hotel facility }\end{array}$ & 4.45 & 4.36 & 4.18 & 4.18 & 4.29 & 3.91 & 0.27 & 0.18 & 1.14 & 0.71 \\
\hline $\begin{array}{l}20 . \quad \text { The attractiveness of } \\
\text { exterior of the hotel facility }\end{array}$ & 4.37 & 4.45 & 4.12 & 4.00 & 4.18 & 3.73 & 0.24 & 0.45 & 1.02 & 1.69 \\
\hline $\begin{array}{l}\text { 21. Online booking possibilities } \\
\text { in the hotel facility }\end{array}$ & 4.31 & 4.55 & 4.31 & 3.91 & 4.41 & 4.18 & 0.00 & 0.64 & 0.00 & 2.66 \\
\hline $\begin{array}{l}22 . \quad \text { The level of your personal } \\
\text { safety and security during your stay } \\
\text { in the hotel facility }\end{array}$ & 4.67 & 4.55 & 4.33 & 3.91 & 4.53 & 4.18 & 0.35 & 0.64 & 1.57 & 2.66 \\
\hline 23. The place of the hotel facility & 4.67 & 4.45 & 4.41 & 4.00 & 4.57 & 4.09 & 0.27 & 0.45 & 1.21 & 1.86 \\
\hline $\begin{array}{l}\text { 24. The time you spend in the } \\
\text { hotel facility }\end{array}$ & 4.43 & 4.27 & 4.37 & 4.09 & 4.39 & 4.09 & 0.06 & 0.18 & 0.27 & 0.74 \\
\hline Total & 4.36 & 4.25 & 4.27 & 3.98 & 4.43 & 4.10 & 0.09 & 0.27 & 0.38 & 1.10 \\
\hline
\end{tabular}

Source: Based on the analysis of the survey results 
(Perceptions-Expectations) column shows the gap between the real performance and expectations of visitors. We see that the main problems were connected with level of cleanliness, level of prices, level of quality and prices of food, the existence of leisure activities in the hotel facility, existence and good functioning of devices, bath convenience.

The level of cleanliness, the existence of leisure activities in the hotel facility, and the bath convenience were mentioned as problems in both hotels.

The overall weighted index for Hotel $\mathrm{X}$ is 0,38 and for Hotel $\mathrm{Y}$ is 1,10 . This shows that although the existence of some problems the guests mainly were satisfied. This fact proves also the findings in the table 1 , that the majority of respondents would like to stay in the same hotel again and would advise others to visit that hotel. This also reveals that in average the guests were satisfied with the quality of hotel services and indicates high level of loyalty for being ready to revisit and advise to others.

I have collected all the 24 determinants of quality in 3 dimensions: tangibles and appearance, availability and comfort, staff competence and helpfulness. Tangibles and appearance describe the physical evidence, aesthetics, cleanliness, facilities and equipment. Availability and comfort describe the existence of some services, their quality and convenience. Staff competence and helpfulness shows the level of responsiveness, knowledge of employees, their ability to inspire confidence, their caring attention to the customers.

Main dimensions of ARMQUAL index in two hotels

\begin{tabular}{|l|c|c|c|c|c|c|c|c|}
\hline Question & \multicolumn{1}{|c|}{$\begin{array}{c}\text { The level of } \\
\text { perception } \\
\text { (satisfaction) }\end{array}$} & \multicolumn{2}{|c|}{$\begin{array}{c}\text { The level of your } \\
\text { expectations }\end{array}$} & \multicolumn{2}{|c|}{$\begin{array}{c}\text { Importance for } \\
\text { you }\end{array}$} & \multicolumn{2}{|c|}{$\begin{array}{c}\text { Index } \\
\text { (P-E)*I }\end{array}$} \\
\hline & X hotel & Y hotel & X hotel & Y hotel & X hotel & Y hotel & $\begin{array}{c}\text { X } \\
\text { hotel }\end{array}$ & $\begin{array}{c}\text { Y } \\
\text { hotel }\end{array}$ \\
\hline $\begin{array}{l}1 . \quad \text { Tangibles and } \\
\text { appearance (Physical } \\
\text { facilities and equipment) } \\
\text { (questions }\end{array}$ & 4.32 & 4.19 & 4.26 & 3.91 & 4.40 & 3.97 & 0.27 & 1.13 \\
$1,2,10,11,12,19,20,23)$ & & & & & & & & \\
\hline $\begin{array}{l}2 . \quad \text { Availability and } \\
\text { comfort (The existence of } \\
\text { some services and their } \\
\text { quality level) (questions 3- } \\
9,13,21)\end{array}$ & 4.20 & 4.08 & 4.24 & 3.90 & 4.42 & 4.11 & -0.20 & 0.75 \\
\hline $\begin{array}{l}3 . \quad \text { Staff competence } \\
\text { and helpfulness } \\
\text { (Responsiveness, } \\
\text { knowledge of employees } \\
\text { and their ability to inspire } \\
\text { confidence, caring } \\
\text { attention to the customers) } \\
\text { (questions } \\
\text { 14,15,16,17,18,22, 24) }\end{array}$ & 4.60 & 4.55 & 4.32 & 4.18 & 4.46 & 4.25 & 1.26 & 1.54 \\
\hline
\end{tabular}

Source: Based on the analysis of the survey results

Table 3 shows that the index is high for the dimesion "staff competence and helpfulness" in both hotels. From the tables 2 and 3 it is clear that in both hotels the factors concerning staff competence, responsiveness, helpfulness, personal safety were evaluated high. The factors of appearance also had high marks. So, this indicates the main factors that have impact on customer satisfaction and loyalty.

In order to find out the relationship between "the level of perception, expectations and importance of factors for the respondents and their desire to revisit and advice others the same hotel" I have derived a hypothesis: 
1. Relationship between the level of perception, expectations and importance of factors for the respondents and their desire to revisit and advice the hotel to other people.

H1: There is a significant relationship between these factors.

H0: There is no significant relationship between these factors.

The cross tabulation and Pearson Chi square testing for hotel X show that in all cases the significance level $a$ is under 0.05 , so this means that we reject the null hypothesis, and there is a significant relationship between the desire of the survey participants to revisit and advise others the same hotel and the level of their perception, expectations and importance of the factors for them (Table 4).

Table 4

Chi-Square Testing

\begin{tabular}{|l|c|c|}
\hline \multirow{2}{*}{} & \multicolumn{2}{|c|}{$\begin{array}{c}\text { Pearson Chi-Square } \\
\text { (X hotel) }\end{array}$} \\
\cline { 2 - 3 } & Value & Approx. Sig. \\
\hline Would you advice others to visit this hotel? * Level of perceptions & 98.000 & 0.000 \\
\hline Would you like to stay in the same hotel again? * Level of expectations & 74.565 & 0.001 \\
\hline Would you advice others to visit this hotel? * Level of expectations & 98.000 & 0.000 \\
\hline Would you advice others to visit this hotel? * Level of importance & 64.623 & 0.001 \\
\hline
\end{tabular}

Source: Based on the analysis of the survey results using SPSS software

The main results of quality indexes were analyzed using Importance-Performance Analysis (IPA) Matrix. The overall quality index of X and Y hotel were placed in the I Quadrant (Figure 1).

Quadrant I or "Keep up the Good Work" has high importance and high performance and shows the competitive advantage of hotels. So, it is important to keep the quality at this level.

Quadrant II or "Concentrate Here" has high importance, but low performance. So this shows that actions are needed to satisfy customers.

Quadrant III or "Low Priority" has low importance and low performance. It shows that the attribute is underperforming, but as it has a low importance for customers, so there is no need to take actions.

Quadrant IV or "Possible Overkill" has low importance, but high performance. It shows that the attribute is successfully performed but has low importance for customers.

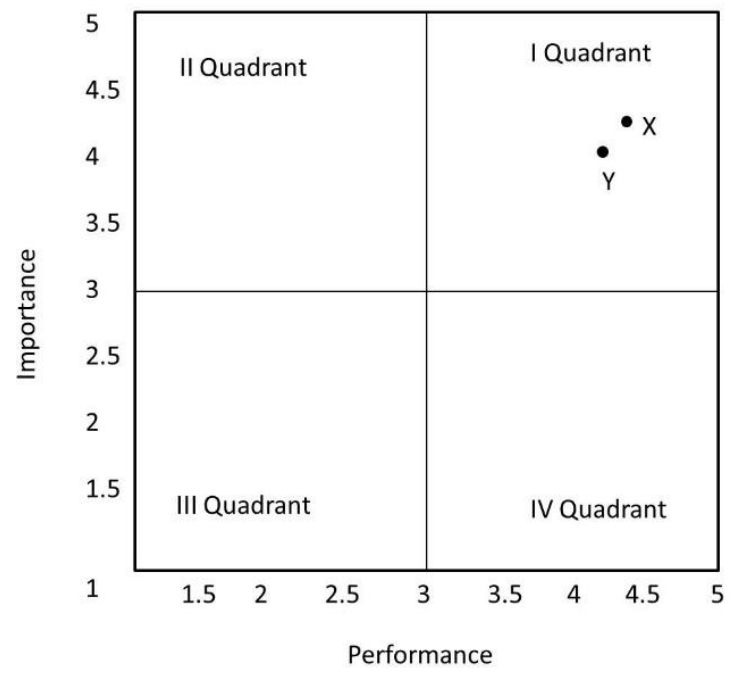

Figure 1. IPA analysis

Source: Processed by the author

The 24 determinants of hotel quality were also analyzed in IPA matrix, using SPSS software.

The intersection point of the (x) and (y) axes in the matrix were determined using medians, from which we define four quadrants. 


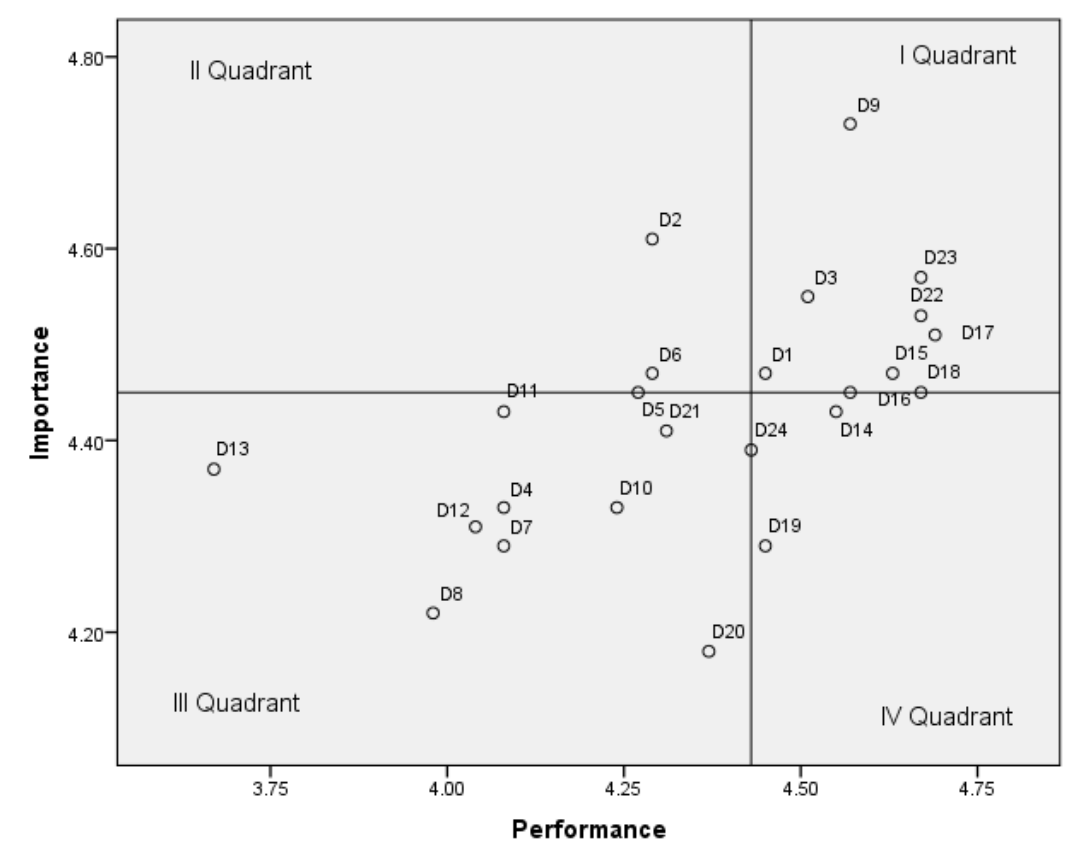

Figure 2. IPA of 24 quality determinants of $X$ hotel

Source: Processed by the author using SPSS

Figure 2 lets define which determinants have competitive advantage and which have problems. The determinants in I quadrant have high performance and high importance, so the hotel should maintain their quality level. At the same time actions should be taken for the determinants in II Quadrant, to raise the level of performance, in order the customers to be satisfied. The determinants in III Quadrant have low importance and low performance, so are minor weaknesses.

In the figure 2 the following determinants are in II Quadrant and need actions: the level of cleanness in the hotel facility, the correlation of price-service quality of the hotel facility, the quality of food in the hotel facility.

The determinants in I Quadrant which have high performance and high importance, are the following: the existence of Wi-Fi and the quality of Internet connection in the hotel facility, the place of the hotel facility, the level of personal safety and security during the stay in the hotel facility, the level of willingness of the staff to help the customer in the hotel facility, quick response of the staff to guests' questions, the caring and polite attitude of the staff of the hotel towards guests, the level of confidence towards the staff of the hotel facility, general conditions of the hotel facility, the level of service in the hotel facility. So, the hotel should maintain the quality level of these determinants.

The IPA for 3 quality dimensions of $\mathrm{X}$ hotel shows that the performance and importance for "Staff competence and helpfulness" is high and is in the I quadrant. 


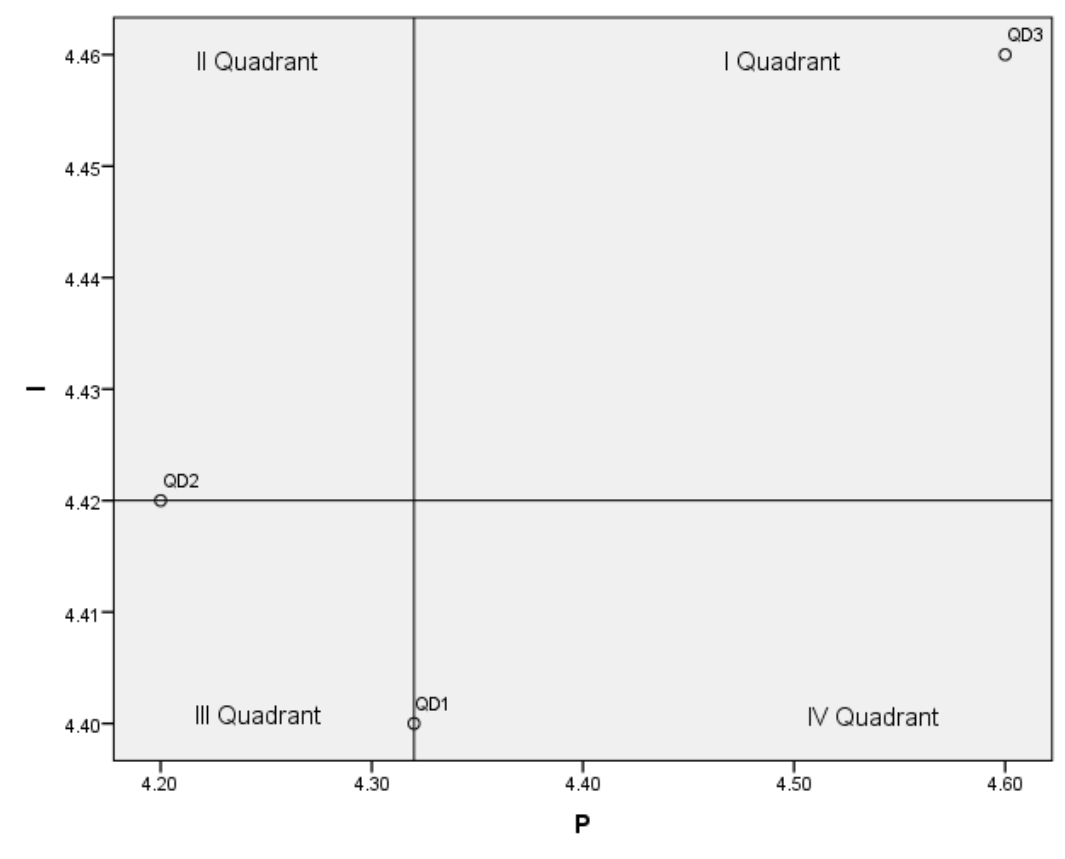

Figure 3. IPA of 3 quality dimensions of $\mathrm{X}$ hotel

Source: Processed by the author using SPSS

So, the results of this study indicate, that the satisfaction of guests lead to loyalty and desire to visit again. This proves the opinion of Petrick (2004), that quality is the best predictor of intentions to repurchase. The results also show the willingness of satisfied customers to advise the hotel to others, which stated Ruyter, Wetzels and Bloemer (1998) in their research that quality has an impact on customer preference and the willingness to recommend the service to other consumers. Besides, Jasinskas et. al. (2016) stated in their study that customers who evaluate service quality high, were more loyal, tended to use the hotel services repeatedly and recommend it to friends.

This study may be a good example for other destinations to evaluate the quality of hotel services, as it does not simply use the existing models of quality evaluation discussed in the literature review. Its originality is that it was processed for Armenian hotels choosing the main determinants of hotel services' quality, which may affect on satisfaction and lead to loyalty. The research results showed that mainly the factors of hotel staff competence and helpfulness were high and although there were some complaints regarding the availability of some services or functioning some devises, however the overall weighted quality rate was positive.

\section{CONCLUSIONS, LIMITATIONS AND RECOMMENDATION FOR FUTURE STUDY}

Thus, the analysis carried out in the paper let us draw some conclusions. First of all, the quality of hotel services for tourists depends on many factors. I have resumed these factors in three main groups: tangibles and appearance, availability and comfort, staff competence and helpfulness. These three groups of factors add the theoretical base in existing literature about hotel quality evaluation. Different instruments use various dimensions, as I have analyzed in the literature review (for example SERVQUAL, LODGSERV, HOLSERV, etc). The dimensions used by me in summary describe all the important spheres of hotel performance and are specific indicators of quality evaluation.

The measurement ARMQUAL lets calculate the service quality based on tourists' perceptions, expectations of the factors and importance for them. The research also reveals the gaps in hotel quality for the selected two hotels, such as the level of cleanliness in the hotel, level of hotel prices, level of quality and prices of food, the existence of leisure activities in the hotel facility, functioning of devices, bath 
convenience, online booking possibilities. So, by such analysis the hotels may reveal the main issues and take steps for regulating them. Besides, the research shows that the index of staff competence and helpfulness dimension was high in two hotels compared with other dimensions.

Pearson Chi square testing reveals relationship between some factors. It proves that the level of perception and expectations influences on the desire to stay in the same hotel again and advice it to others.

The Importance-Performance Analysis (IPA) lets determine the quadrants of the quality determinants in order to take actions towards raising the level of performance.

Of course, hotel quality plays an important role in satisfying tourist needs. If tourists are satisfied, they may return again the same hotel or tell their friends to visit it. That is why, hotels must use service quality evaluation tools for improving their performance.

As a summary, this study has not only theoretical, but also empirical significance for the sphere. This is the first attempt to create such a comprehensive instrument, test it via surveys and analyses and draw conclusions. Besides, testing the survey results via Importance-Performance analysis enabled to determine the gap between the importance of the factors for the customer and the perceived level of the service for identifying the competitive positions of factors and choosing available strategies to enhance the performance level.

Apart from the main theoretical and empirical implications of this study, it has few limitations. First, the evaluations are based on customers' ratings within the scale 1 to 5 . The results show the average scores. However, it mainly reflects the main experience by hotel guests, and in some cases additional analyses may be done (for example, if hotels do not agree with the guests responses, or they think that guests deliberately have evaluated lower, they may try to find out what was the problem, but in this survey the results mainly reflected the average perceptions and were realistic). Secondly, the analysis was done only in two hotels. The number of overall respondents was 100 . Future studies should enlarge the survey by including other hotels and more respondents. This was the beginning to try the instrument and find out the key issues available in hotel industry. Moreover, future studies will try to find different results (if there are any) by testing ARMQUAL instrument in many hotels of different destinations in Armenia. Now some hotels use their own questionnaires for evaluating the quality of their services and their guests' satisfaction levels. This instrument is a good tool including various factors, and its application in all hotels will let evaluate and compare hotels with the same determinants.

Hotel industry has a significant role in tourism. Good or bad experience in a hotel facility may have an impact on overall tourist satisfaction level. A comfortable hotel, which has all the components for a good rest, helpful and competent staff ready to response quickly to customer needs, good location, physical evidence, easy access, availability of many services, leisure possibilities, level of safety in the hotel - all these factors are crucial components for evaluating the quality of hotel services. Thus, the ARMQUAL instrument included all the factors and based on it I could evaluate the quality level in two hotels. The instrument may be used by hotels as a complex instrument for quality evaluation.

\section{REFERENCES}

Baquero, A., Delgado, B., Escortell, R., \& Sapena, J. (2019). The influence of transformational and authentic leadership on the satisfaction of hotel customers in the Canary Islands. Tourism and Hospitality Research, 0(0), 1-14, https://doi.org/10.1177/1467358419891458

Bayol, M., Foye, A., Tellier, C., \& Tenenhaus, M. (2000). Use a PLS path modeling to estimate the European customer satisfaction index (ECSI) model. Statistica Applicata, 12(3), 361-375.

Chiu, H. \& Chen, C. (2014). Advertising, price and hotel service quality: a signalling perspective. Tourism Economics, 20(5), 1013-1025. doi: 10.5367/te.2013.0324

Cronin Jr, J. J., \& Taylor, S. A. (1992). Measuring service quality: a reexamination and extension. Journal of Marketing, 56(3), 55-68. 
Domi, S., Keco, R., Capelleras, J.-L., \& Mehmeti, G. (2019). Effects of innovativeness and innovation behavior on tourism SMEs performance: The case of Albania. Economics and Sociology, 12(3), 67-85. doi:10.14254/2071789X.2019/12-3/5

Fornell, C. (1992). A national customer satisfaction barometer, the Swedish experience. Journal of Marketing, 56, 6-21.

Fornell, C., Johnson, M. D., Anderson, E.W., Cha, J., \& Bryant, B. E. (1996). The American customer satisfaction index: Nature, purpose, and findings. Journal of Marketing, 60, 7-18.

Heide, M., \& Grønhaug, K. (2009). Key factors in guests' perception of hotel atmosphere. Cornell Hospitality Quarterly, 50(1), 29-43. doi:10.1177/1938965508328420

Heung, V. C., \& Wong, M. Y. (1997). Hotel service quality in Hong Kong: A study of tourists' expectations. Journal of Vacation Marketing, 3(3), 264-271. doi.org/10.1177/135676679700300307

Jasinskas, E., Streimikiene, D., Svagzdiene, B., \& Simanavicius, A. (2016). Impact of hotel service quality on the loyalty of customers. Economic research-Ekonomska istraživanja, 29(1), 559-572. doi: 10.1080/1331677X.2016.1177465.

Johnson, M. D., Gustafsson, A., Andreassen, T. W., Lervik, L., \& Cha, J. (2001). The evolution and future of national customer satisfaction index models. Journal of Economic Psychology, 22, 217-245.

Knutson, B., Stevens, P., Wullaert, C., Patton, M., \& Yokoyama, F. (1990). LODGSERV: A service quality index for the lodging industry. Hospitality Research Journal, 14(2), 277-284. https://doi.org/10.1177/109634809001400230

Lai, I. K. W. (2019). Hotel image and reputation on building customer loyalty: An empirical study in Macau. Journal of Hospitality and Tourism Management, 38, 111-121. https://doi.org/10.1016/j.jhtm.2019.01.003

Lewis, R. C., \& Booms, B. H. (1983). The marketing aspects of service quality. Emerging perspectives on services marketing, 65(4), 99-107.

Martilla, J.A.\& James, J.C. (1977) Importance-Performance Analysis. Journal of Marketing, 41, 77-79.

Mei, A. W. O., Dean, A. M., \& White C. J. (1999). Analysing service quality in the hospitality industry'. Managing Service Quality, 9(2), 136-143.

Parasuraman, A., Zeithaml, V. A., \& Berry, L. L. (1988). Servqual: A multiple-item scale for measuring consumer perc. Journal of retailing, 64(1), 12-40.

Parasuraman, A., Zeithaml, V. A., \& Berry, L. L. (1985). A conceptual model of service quality and its implications for future research. Journal of marketing, 49(4), 41-50.

Pelegrín-Borondo, J., Arias-Oliva, M., \& Olarte-Pascual, C. (2017). Emotions, price and quality expectations in hotel services. Journal of Vacation Marketing, 23(4), 322-338. doi:10.1177/1356766716651305

Petrick, J. F. (2004). The roles of quality, value, and satisfaction in predicting cruise passengers' behavioral intentions. Journal of travel research, 42(4), 397-407. doi: 10.1177/0047287504263037

Qu, H., \& Tsang, N. (1998). Service quality gap in China's hotel industry: A study of tourist perceptions and expectations. Journal of Hospitality \& Tourism Research, 22(3), 252-267. https://doi.org/10.1177/109634809802200304

De Ruyter, K., Wetzels, M., \& Bloemer, J. (1998). On the relationship between perceived service quality, service loyalty and switching costs. International Journal of Service Industry Management, 9(5), 436-53.

Sanjay, J.K,. \& Garima, G., (2004). "Measuring Service Quality: SERVQUAL vs. SERVPERF Scales”, VIKALPA, V. 29(2), 25-37.

Shahin, A., (2006). SERVQUAL and Model of Service Quality Gaps: A Framework for Determining and Prioritizing Critical Factors in Delivering Quality Services, Service Quality-An Introduction, The ICFAI University Press, India, pp. 117-132.

The socio-economic situation in January 2019 in the RA, p. 105, URL: https://www.armstat.am/file/article/sv_01_19a_421.pdf (Accessed 01.04.2019)

Yang, Y., Mao, Z., \& Tang, J. (2018). Understanding guest satisfaction with urban hotel location. Journal of Travel Research, 57(2), 243-259. https://doi.org/10.1177/0047287517691153

Yang, X., Tian, P., \& Zhang, Z. (2000). A comparative study on several national customer satisfaction indixes (CSI). URL:

https://www.vanhaaften.nl/images/documents/pdf/A\%20Comparative\%20Study $\% 20$ on $\% 20$ Several $\% 20$ National $\% 20$ Custo mer\%20Satisfaction.pdf

Zeithaml, V. A. (1988). Consumer perceptions of price, quality, and value: a means-end model and synthesis of evidence. Journal of marketing, 52(3), 2-22.

Zoghbi-Manrique-de-Lara, P., Suárez-Acosta, M. A., \& Aguiar-Quintana, T. (2014). Hotel guests' responses to service recovery: How loyalty influences guest behavior. Cornell Hospitality Quarterly, 55(2), 152-164. https://doi.org/10.1177/1938965513513348. 


\section{APPENDIX 1: QUESTIONNAIRE FOR EVALUATING THE QUALITY OF HOTEL SERVICES IN ARMENIA}

1. Age

2. Nationality, place of residence (city, country)

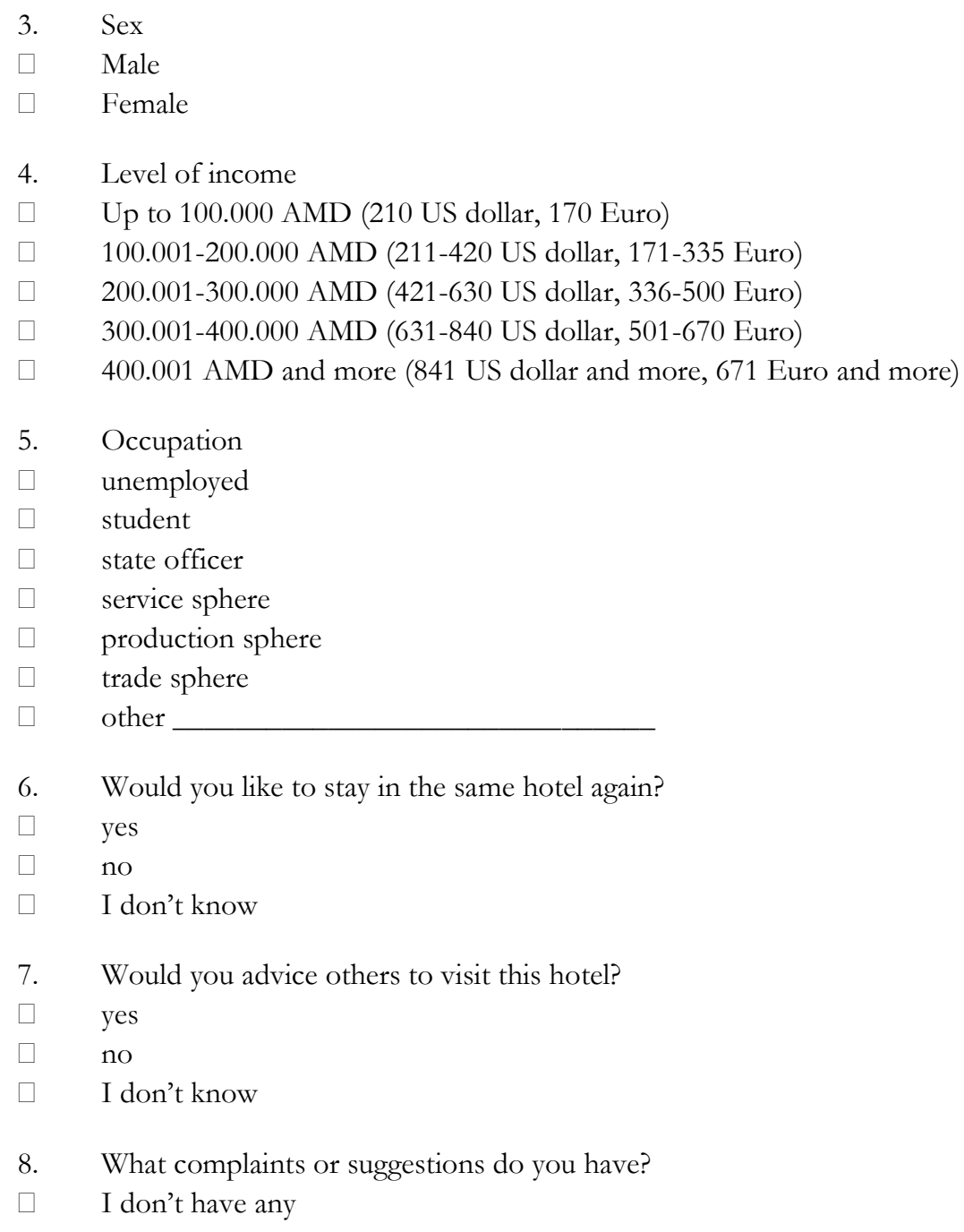

9. Evaluate these items for your expectations (Very low-1, Low-2, Medium-3, High-4, Very high-5), perceived performance (Very dissatisfied-1, Dissatisfied-2, Somewhat satisfied-3, Satisfied-4, Very satisfied-5) and importance for you (Not important at all-1, Not important-2, Of medium importance-3, Important-4, Very important-5) 


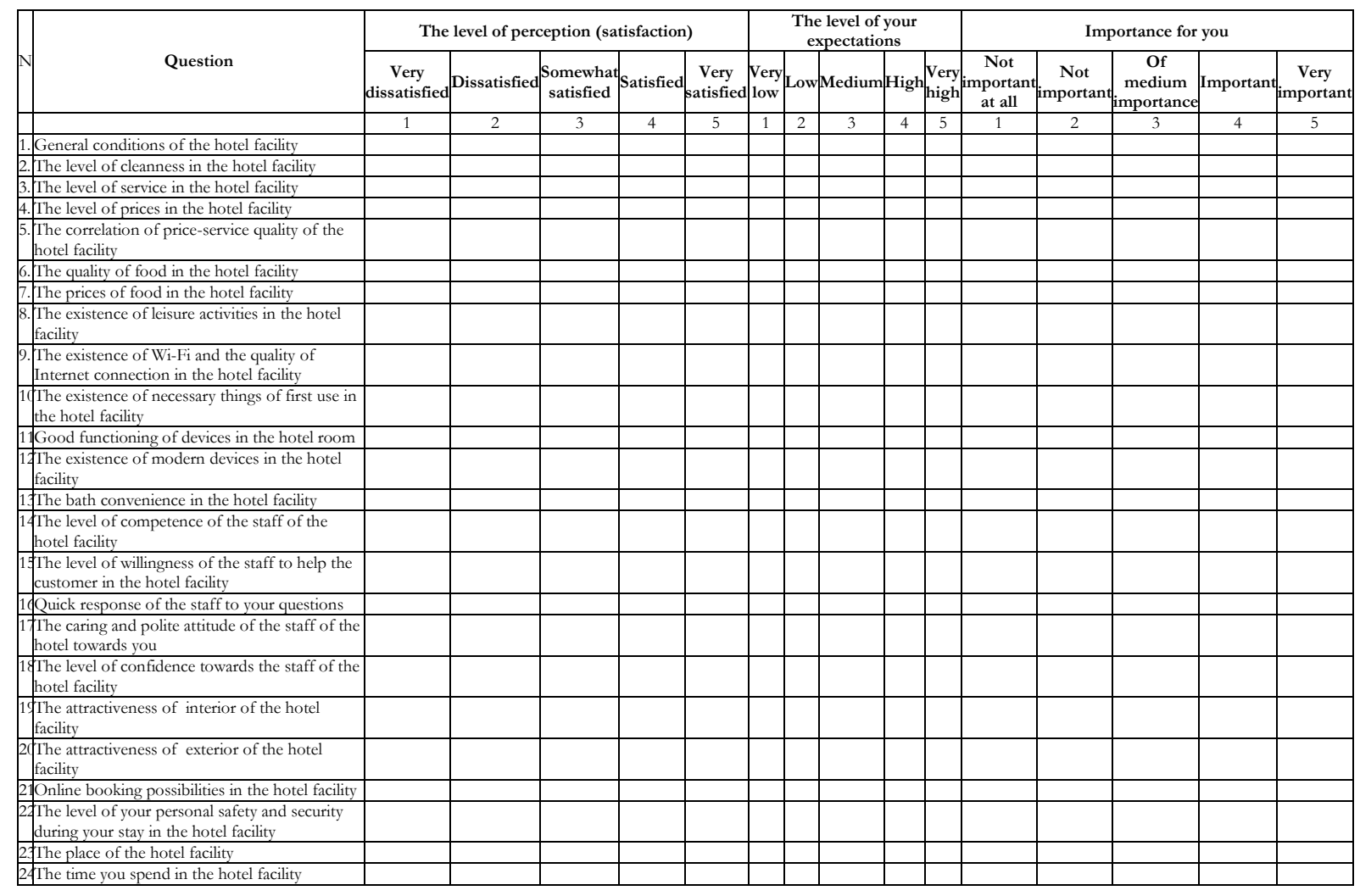

